\title{
Detection of marine microalgae (phytoplankton) quality to support seafood health: A case study on the west coast of South Sulawesi, Indonesia
}

\author{
RAHMADI TAMBARU`, ANDI I. BURHANUDDIN, ARNIATI MASSINAI, MUHAMMAD A. AMRAN \\ Department of Marine Science, Faculty of Marine Science and Fisheries, Universitas Hasanuddin. Jl. Perintis Kemerdekaan Km 10, Tamalanrea, \\ Makassar 90425, South Sulawesi, Indonesia. Tel./fax.: +62-411-586025, `email: aditbr69@unhas.ac.id
}

Manuscript received: 11 October 2021. Revision accepted: 29 October 2021.

\begin{abstract}
Tambaru R, Burhanuddin AI, Massinai A, Amran MA. 2021. Detection of marine microalgae (phytoplankton) quality to support seafood health: a case study on the west coast of South Sulawesi, Indonesia. Biodiversitas 22: 5179- 5186. The research aimed to detect marine microalgae quality to support seafood health was carried out from January to November 2020 along the west coast of South Sulawesi, Indonesia. Samples were collected from the coastal waters of Pangkep District, Maros District, and the northern part of Makassar City. Phytoplankton cell counts were obtained using the deposition method developed by Uthermol. Phytoplankton cell abundances were calculated through sweeping (census) using a Sedgwick Rafter Cell (SRC). Two-way analysis of variance (ANOVA) was used to compare the distribution of marine microalgae community abundance between observation stations and periods. Based on the types and relative abundance of phytoplankton present, i.e., harmful algal bloom (HAB) forming or not (non-HAB), the results showed the quality of marine microalgae, specifically, phytoplankton was relatively good. Many more non-HAB (94-98\%) than HAB (2-6\%) marine microalgae were detected. Thus, the phytoplankton flourishing in these waters is mostly suitable as food for other organisms, including fish and shellfish. This also means that if fishers harvest these fish and shellfish, they should be fit and safe for human consumption.
\end{abstract}

Keywords: HABs, health, marine, microalgae, phytoplankton, seafood

\section{INTRODUCTION}

Microalgae are the most common and abundant unicellular organisms found in all water bodies, including coastal and marine waters (George et al. 2012; Desrosiers et al. 2013). These organisms are a group of microscopic plants, some of which are single-celled while others are colonial, which live in all seas and freshwater bodies. These microalgae are often referred to as phytoplankton (Sunda 2012; Shadrin et al. 2017).

Periodic increases in microalgae populations are natural phenomena (Visciano et al. 2016). They do not always cause detrimental effects so long as algal growth remains within normal limits and does not cause a significant disturbance to the surrounding ecosystems (Gao et al. 2020). However, if there is a dramatic increase in the population of unwanted or harmful organisms, the situation can require an immediate response (Zohdi and Abbaspour 2019). These population explosions can trigger problems that impact the lives of other organisms; examples include mass fish kills (Work et al. 2017), the contamination of seafood leading to public health problems (food poisoning) (Kudela et al. 2018), and changes to aquatic ecosystem community structure (Lu et al. 2018; Todd et al. 2019).

Rapid or excessive increases in the microalgae (phytoplankton) population, termed algal blooms, can occur when environmental conditions are conducive to algal growth and reproduction (Glibert 2017; Paerl et al 2018; Meesters and Tapilatu 2020). When phytoplankton population explosions include toxic microalgae, they can be extremely dangerous (Tian et al. 2018). These phenomena involving toxic microalgae are generally termed Harmful Algae Blooms, more often referred to by the acronym HABs, and have adverse effects on local coral reef, fishery resources, including mariculture and capture fisheries commodities such as oysters, shellfish, and fish (Anderson et al. 2015; Berdalet et al. 2016; Glibert 2017; Brown et al. 2019; Meesters and Tapilatu 2020).

Over time, environmentalists have become increasingly concerned about the incidence of HABs (Sha et al. 2021). Frequently discussed topics include the emergence of new types of HAB, the rising frequency of occurrence, the expansion of the geographic area affected, and the prolonged duration of their occurrence (Fu et al. 2012; Anderson et al. 2015; Wells et al. 2015; Berdalet et al. 2016; D'Costa et al. 2017; Paerl et al. 2018; Xiao et al. 2019; Trainer et al. 2020). Recent studies have also found novel toxins in HABs (Anderson et al. 2015; Lassus et al. 2016). These factors all contribute to increases in HABassociated mortality of marine organisms (Fukuyo et al. 2011).

HABs are phenomena that commonly occur in water bodies, especially marine and coastal waters. HABs occur when certain groups of phytoplankton (HABs forming species) experience population explosions and have negative impacts on other aquatic organisms as well as on human health (Berdalet et al. 2016, 2018). According to Xiao et al. (2019), the factors that can trigger a 
phytoplankton population explosion that can be qualified as a HABs include nutrient enrichment (eutrophication), the occurrence of heavy rains increasing the flow of nutrientloaded river water into the sea (Hughes et al. 2011), and upwellings (Loureiro et al. 2011).

Some of the acute diseases caused by toxins from microalgae in the HABs group are paralytic shellfish poisoning (PSP), amnesic shellfish poisoning (ASP), diarrhetic shellfish poisoning (DSP) (Fukuyo et al. 2011; Krock et al. 2018), and ciguatera fish poisoning (CFP) (Skinner et al. 2011). These toxins are hazardous to human health because they attack the nervous system and interfere with respiration and digestion. These diseases are related to the human consumption of fish and shellfish. Many types of toxic phytoplankton can be found in Indonesian coastal waters, including several Dinoflagellate species from the genera Noctiluca, Gymnodinium, Cochlodinium, Ceratium, Peridinium, Gonyaulax, Ostreopsis, Prorocentrum, and Gambierdiscus (Adnan 1984; Adnan 1989; Skinner et al. 2011; Hasani et al. 2013; Aditya et al. 2015). One HAB event in 1993 took place in Jakarta Bay, where a mass fishkill was caused by the excessive abundance of phytoplankton that can cause HABs. Similar HAB incidents have occurred in the waters of Lewotobi and Lewouran (East Nusa Tenggara), Sebatik Island (East Kalimantan), and Ambon Bay (Mahmudi et al. 2020).

Other events of interest have been observed in the northern and southern coastal waters of South Sulawesi. In November 2014, a mass fish-kill incident took place in estuarine coastal waters of Pangkep District, attracting public attention and suddenly creating awareness in an area where such an incident had never happened before. Environmental experts put forward various hypotheses to explain the mass fish-kill; causal factors proposed included pollution by organic matter, reduced oxygen content, the blooming of certain types of phytoplankton, and a decrease in the quality of river sediment (Rukminasari and Tahir 2020). Furthermore, in August 2016, around 63 local residents were poisoned due to eating shellfish, specifically clams or cockles of the genus Anadara. The clams were collected in the coastal waters of Mallasoro Village (on the south coast of South Sulawesi in Bangkala District, Jeneponto District. It is suspected that the clams were contaminated with toxins from potentially dangerous (toxin-producing) phytoplankton. Thus, more research is required to test the hypotheses and provide definitive answers regarding the incidents mentioned earlier.

Microalgal blooms can occur, are known to contaminate aquatic organisms such as fish and shellfish, and may have been a factor in both cases. In the Pangkep region, aquaculture and mariculture activities are common in both riverine and coastal waters (Lestari et al. 2021). In some cases, use various drugs and fertilizers to increase production; this is also the case in the coastal waters of Mallasoro Village, Jeneponto District, South Sulawesi. To date, there has not been any definitive answer regarding the factors which caused the two aforementioned possible HAB events. However, the potential role of the ongoing nutrient enrichment of riverine and coastal waters is one strong reason to justify analyzing the phytoplankton community and monitoring change, specifically regarding the types of microalgae that can form HABs. Increases and or changes in nutrient concentration can occur due to seasonal changes between the east and west monsoons (Vajravelu et al. 2018; Rastina et al. 2020). These fluctuations will impact the microalgal communities, including the presence of HAB forming species whose presence can be seasonal (Narale and Anil 2017; Vajravelu et al. 2018; Trainer et al. 2020), and can therefore become a factor triggering the emergence and rapid growth of HABs.

There is a lack of comprehensive research on the presence and development of HABs in the coastal waters of South Sulawesi. The information available regarding the $\mathrm{HAB}$-forming microalgae which may occur in the region is limited and partial. However, HABs species have been reported incidentally or as a small part of some studies in the waters of South Sulawesi with limited spatial or temporal coverage (Mujib et al. 2015; Rukminasari and Tahir 2020; Samawi et al. 2020; Lestari et al. 2021). Meanwhile, information on HAB forming phytoplankton is crucial for anticipating and early detection of HABs, and a basis for evaluating the quality of coastal waters concerning the potential impacts on the life of organisms at higher tropical levels (Glibert 2017).

To evaluate the prevalence of HAB forming phytoplankton, this study aimed to detect the quality of marine microalgae to support seafood health in a case study on the west coast of South Sulawesi, Indonesia. This research relates to the lives and livelihoods of the local communities, especially fishermen who depend on the coast and the sea for their lives. It will be of benefit through providing up-to-date data and information on the quality of marine microalgae along the west coast of South Sulawesi, in order to inform sustainable management of coastal resources, as an early detection mechanism for HABs-associated risks, and as a tool for evaluating water quality in the region.

\section{MATERIALS AND METHODS}

\section{Research site and timeframe}

The research was conducted from June to November 2020. Data were collected in the coastal waters off the west coast of South Sulawesi Province, Indonesia, during three periods (Table 1). The four research sites (Figure 1) were in Pangkep District (PK), Maros District (Kuri: KR, and Maros: MR), and the northern waters of Makassar City (Tallo: TL).

Table 1. Timing of sample collection and in situ measurement of parameters

\begin{tabular}{lll}
\multicolumn{1}{c}{ Period } & Time of day & \multicolumn{1}{c}{ Season } \\
\hline Jun-Jul 2020 & 10:00-16:00 & Dry season \\
Aug-Sep 2020 & 10:00-16:00 & Dry to the rainy season \\
Octr-Nov 2020 & 10:00-16:00 & Beginning of the rainy season \\
\hline
\end{tabular}




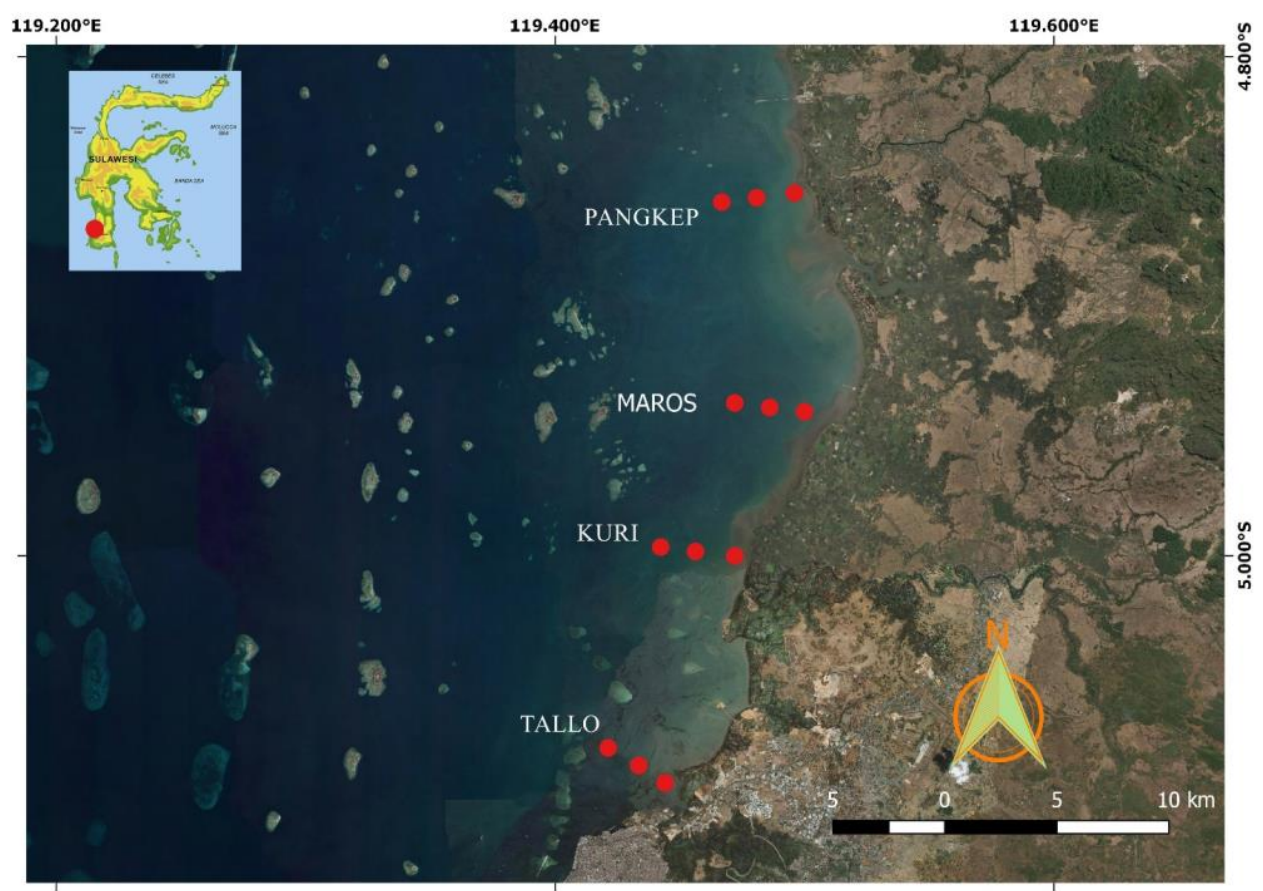

Figure 1. Map of sampling sites in the waters off the west coast of South Sulawesi, Indonesia

\section{Materials and research design}

The primary materials used in this research were seawater samples collected from three zones along an onshore-offshore gradient at each of the four stations during each period. Several oceanographic parameters were measured in the field (in situ), while others were measured in the laboratory. This study was non-experimental. The variables were observed without any manipulation or intervention by the researchers. The variables analyzed were the abundance and composition of the phytoplankton community, which included both $\mathrm{HAB}$ and non-HAB forming species.

\section{Phytoplankton analysis in the laboratory}

Seawater samples were collected using a 2 L Kemmerer Water Sampler. At each site, $1 \mathrm{~L}$ of water was taken from each station (zone) to count and identify phytoplankton in the laboratory. Phytoplankton cells were precipitated out of the samples using the method developed by Utermöhl (Vadrucci et al. 2018). A $100 \mathrm{~mL}$ sub-sample was placed in a measuring beaker (volume $100 \mathrm{~mL}$ ) and preserved in Lugol solution for one week. Once precipitation had occurred, the precipitated material $(10 \mathrm{~mL})$ was separated from the supernatant by siphoning the supernatant out of the beaker. This precipitate was then placed in a bottle to which more Lugol solution was added. The abundance of phytoplankton cells was calculated using a sweeping (census) method (Rocha et al. 2015) using a $50 \mathrm{~mm}$ x 20 mm x $1 \mathrm{~mm}$ Sedgwig Rafter Cell (SRC). A $1 \mathrm{~mL}$ aliquot of the precipitate was placed in the SRC using a graduated pipette. The SRC was observed under a binocular microscope (Olympus CX21) at 10x10 magnification. Phytoplankton cells were identified using several standard reference works (Tomas 1997; Castellani and Edwards 2017).

\section{Statistical analysis}

The data were analyzed descriptively through tabulation and graphical approaches. These included the use of graphs and maps to represent the taxonomic composition and the spatial and temporal distribution of the microalgae identified. A two-way analysis of variance (ANOVA) was used to evaluate the spatial and temporal differences in microalgal community abundance, in particular that of HAB-forming phytoplankton. Post-hoc Tukey tests were carried out if the ANOVA indicated significant differences at the $95 \%$ confidence level ( $\alpha$ : 0.05$)$. Prior to testing, all parameters were first tested for normality of the data distribution using Kolmogorov-Smirnov and Levene's Test of Equality. These analyses were implemented in SPSS 17 and Excel Stat 2017 (Brahem et al. 2017).

\section{RESULTS AND DISCUSSION}

\section{Detection of marine microalgae (phytoplankton)}

During this study, 22 phytoplankton genera belonging to 3 classes were identified. These comprised 16 genera of the Class Bacillariophyceae, 1 genus of the Class Cyanophyceae, and 5 genera of the Class Dinophyceae. The genus-level composition varied spatially (between sites/stations) and temporally (between study periods); however, for almost all sampling periods and sites, the dominant phytoplankton genera were Chaetoceros, Coscinodiscus, Nitzschia, Odontella, and Rhizosolenia, all of which belong to the Class Bacillariophyceae. 
The phytoplankton density in the samples (Figure 2) indicates relative abundance. Over the study period, mean phytoplankton abundance was higher at the Tallo and Kuri sites than at the Maros and Pangkep sites. The analysis of variance indicated a significant difference in phytoplankton abundance between the sites/stations $(p<0.01)$. The observed phytoplankton abundance also varied between the periods. However, the analysis of variance indicated that the differences in the abundance of phytoplankton over time were not statistically significant throughout observation $(p>0.05)$

Types of marine microalgae (phytoplankton) considered dangerous because they can form HABs were present at almost all sites/stations (Figure 3). The taxa identified included 5 potentially HAB-forming phytoplankton genera belonging to the Class Dinophyceae: Ceratium, Dinophysis, Gymnodinium, Prorocentrum, and Protoperidinium (Figure 4). These genera were present in most sites/stations and observation periods.

The presence and abundance of the potentially HAB forming taxa varied between sites/stations and periods of observation (Figure 3). The analysis of variance revealed highly significant differences $(p<0.01)$ in the abundance of HAB forming taxa between sites/stations.

\section{Quality of marine microalgae (phytoplankton)}

The phytoplankton identification and counts revealed that non-HAB phytoplankton were both more taxonomically diverse and far more abundant than the HAB phytoplankton. The non-HAB phytoplankton comprised 94-98\% of the microalgae cells, counted while HAB forming phytoplankton accounted for 2-6\% (Figure 5).

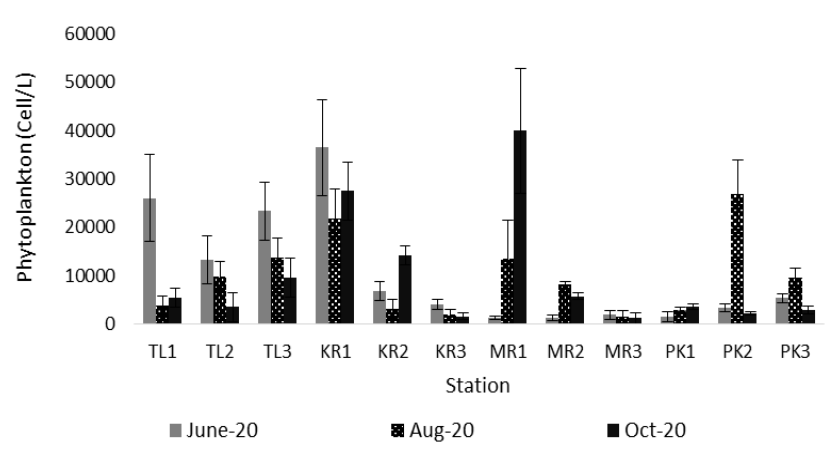

Figure 2. Phytoplankton density at the sampled sites in South Sulawesi over the research period (mean \pm SD)

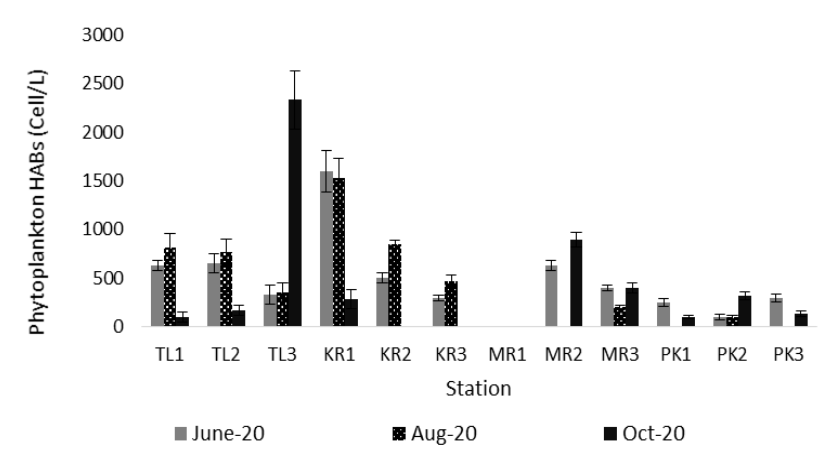

Figure 3. HAB forming phytoplankton density in samples from South Sulawesi over the study period (mean \pm SD)
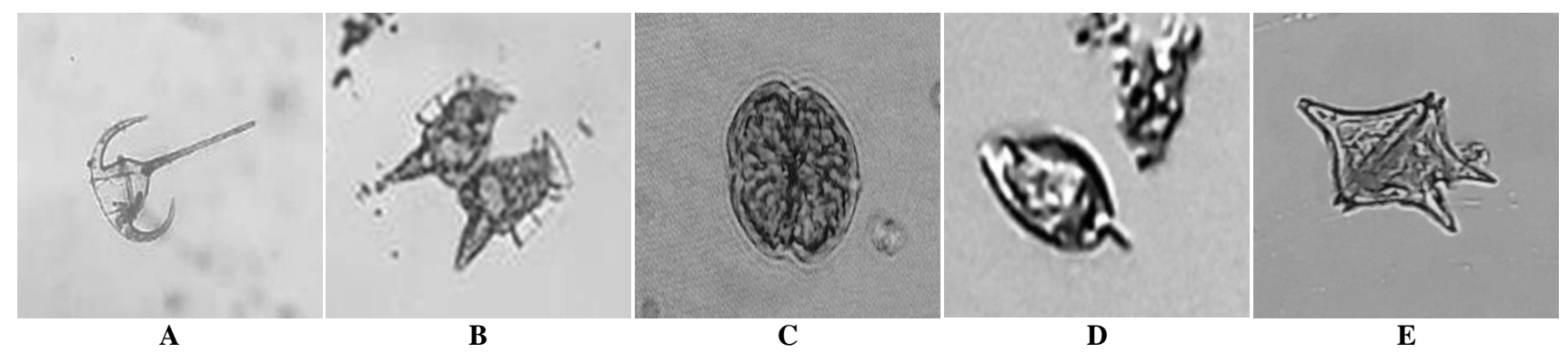

Figure 4. Examples of phytoplankton from class Dinophyceae. A. Ceratium, B. Dinophysis, C. Gymnodinium, D. Prorocentrum, E. Protoperidinium

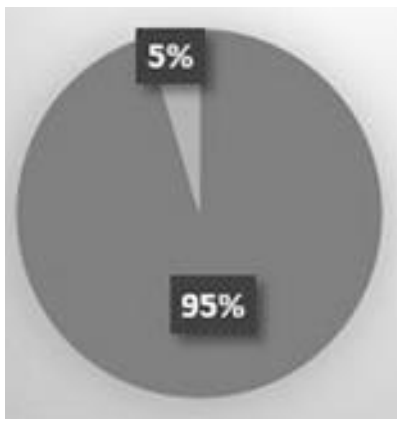

$\mathbf{A}$

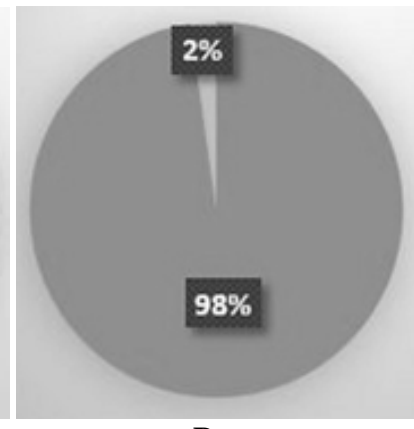

B

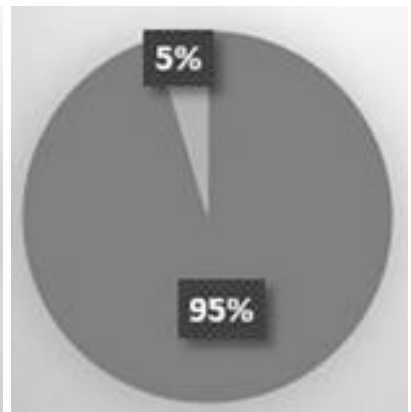

C

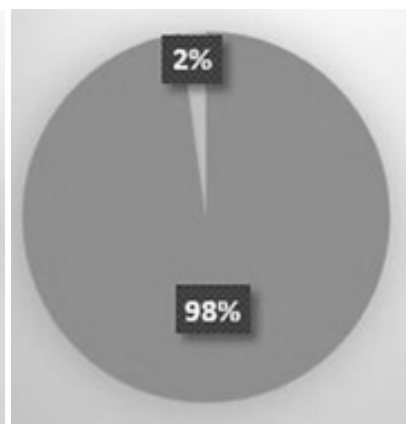

D

Figure 5. Relative abundance (proportion) of HABs and non-HABs phytoplankton observed during the research period. A. Tallo, B. Kuri, C. Maros, D. Pangkep 


\section{Discussion}

The dynamics of marine microalgal communities vary from one site to another and from one time to another. Changes in community composition frequently occur (Marinov et al. 2010; Fujiwara et al. 2018). The survival and replication of phytoplankton are greatly influenced by various environmental parameters (Baek et al. 2020). In response to environmental changes, these microalgal communities will comprise different types of phytoplankton with shifts in the relative abundance of each type. At certain times some groups are found to be abundant, at other times other groups will dominate the community (Thovyan et al. 2020).

Changes in various environmental parameters have an impact on the population dynamics of the phytoplankton that can cause HABs (Cui et al. 2018). If these changes favor the growth and replication of HAB-forming taxa, the equilibrium of the ecosystem can be affected, reducing the quality of marine microalgae with knock-on effects on other organisms. Ecologically, phytoplankton forms the basis of most food chains; thus, their abundance and composition affect the existence of almost all aquatic biota (Brett et al. 2009; Cavicchioli et al. 2019). Therefore, information on the characteristics of the phytoplankton present in particular waters can indicate their ability to support aquatic life. During the study, five genera were dominant at almost all sites/stations and observation periods: Chaetoceros, Coscinodiscus, Nitzschia, Odontella, and Rhizosolenia. All of these species belong to the Class Bacillariophyceae. Chaetoceros were the most abundant genus and classes for all sites, zones, and periods of observation. These taxa are often present at high densities in marine waters worldwide (Sunesen et al. 2008; Angara et al. 2013), including Indonesia (Takarina et al. 2019). Usually, Chaetoceros species are abundant in areas where nitrogenous nutrients, especially nitrates, are below the optimal concentration range for the growth of phytoplankton. Indeed, Ferreira et al. (2020) stated that Chaetoceros can still exhibit comparatively fast growth when low N-type nutrient concentrations.

The Tallo site/stations had the highest phytoplankton abundance, differing significantly from Maros and Pangkep $(\mathrm{p}<0.01)$; however, the abundance at the Kuri site was not significantly different from that at Tallo. Different results occurred in observing the abundance of phytoplankton based on the observation period. Based on the analysis of variance, the abundance of phytoplankton was not significantly different based on the period of observation $(p>0.05)$. The analysis results are supported by in-situ water quality parameters, as several parameters that can affect phytoplankton growth had almost the same value during the three periods.

Types of marine microalgae which are considered dangerous as HABs forming phytoplankton were present at almost all sites/stations (Figure 3). These observations are an important finding as, under certain conditions, these microorganisms can negatively affect water quality if they multiply excessively (blooming), endangering the lives of other aquatic organisms, even humans when they become dominant. Through the food chain, the accumulation of toxins in the body of organisms that consume HABs forming microalgae can cause health problems and even death in humans (Pettersson and Pozdnyakov 2013).

The taxa identified included five potentially HABs forming phytoplankton genera belonging to the Class Dinophyceae: Ceratium, Dinophysis, Gymnodinium, Prorocentrum, and Protoperidinium. These genera were present in most sites/stations and observation periods. The classification of these taxa as presenting a risk of HABs can be justified because the Dinophyceae contain the most toxic genera (Tillmann et al. 2010). These five HABs genera produce toxic metabolites, so they belong to the toxin producer group (Kudela et al. 2018). If these metabolites accumulate in the bodies of marine organisms such as shellfish and fish, they can cause poisoning in humans who consume this seafood (Farabegoli et al. 2018).

The abundance of HABs in surface waters can be influenced by aquatic sediment dynamics. HABs can remain for long periods in aquatic sediments in the form of cysts, such as Gymnodinium cysts from the Class Dinophyceae (Dzhembekova et al. 2018). According to Fukuyo et al. (2011), phytoplankton in this class play an important role in recurring $\mathrm{HAB}$ events and contribute to the geographical expansion of HAB occurrences. These repeat $\mathrm{HABs}$ can occur when many cysts of potentially HAB-forming Dinophyceae are deposited in marine sediments (Narale and Anil 2017; Trainer et al. 2020). Turbulence can disturb the sediment and raise these cysts to the surface layer of the water. Such events can trigger an explosion of HABs if prevailing environmental conditions support their growth.

Ceratium does not belong to the toxic phytoplankton group. However, this genus can cause various problems in the waters if it blooms (Praseno and Sugestiningsih 2000). In addition, this organism is considered to be a threat to the aquatic environment because it can cause oxygen deprivation through decreasing oxygen concentration in the water. Ceratium can result in mass mortality of marine life due to decreased oxygen levels if the population becomes too abundant (Thoha and Rachman 2012). Dinophysis belongs to the HAB-forming group because it contains toxins that can cause diarrhetic shellfish poisoning (DSP) if humans consume contaminated shellfish (Taylor et al. 2013). According to (Dietrich et al. 2019), the symptoms of poisoning caused by Dinophysis (DSP) include diarrhea induced by okadaic acid. Gymnodinium is a type of HABforming phytoplankton that causes red tides and oxygen depletion (Pitcher and Probyn 2016). Gymnodinium can cause paralytic shellfish poisoning (PSP) so that consuming contaminated shellfish can cause paralysis in humans (Rodrigues et al. 2012). Protoperidinium species contain toxins called azaspiracids; the symptoms in humans who ingest this poison are somewhat similar to those of DSP, and poisoning can cause nausea in the victim within 3-5 days (Trainer et al. 2013).

The presence and abundance of the $\mathrm{HAB}$ forming taxa varied significantly (ANOVA, $p<0.01$ ) between sites/stations and periods of observation (Figure 3). While visually Tallo and Kuri appear to differ from the Maros and Pangkep sites, the Tukey test showed that the Pangkep site 
differed significantly from the other three sites (Tallo, Kuri, and Maros). Although the abundance of HAB taxa differed between the periods, the lack of statistical significance (ANOA, $p>0.05$ ) indicates that the presence and abundance of taxa capable of forming HABs can be considered similar throughout the study period.

Overall, the quality of marine microalgae is determined by the types and relative abundance of phytoplankton that can form HABs (HAB) and those which do not form HABs (non-HAB) phytoplankton in the water. HAB-forming phytoplankton can multiply rapidly when changes occur in ambient environmental conditions. The Dinophyceae can tolerate environmental changes such as nutrient enrichment (eutrophication) (Tester et al. 2020). If eutrophic conditions occur, phytoplankton from the Dinophyceae will tend to multiply more rapidly and may form HABs (Glibert 2017). Once the HABs have begun to form, non-HAB phytoplankton may experience a decline in abundance and or diversity (Glibert 2020; Lestari et al. 2021). One reason for this decline is that when the HABs phytoplankton is multiplying, they release toxins (Glibert 2017, 2020); these may impede the growth and reproduction of the non-HAB phytoplankton as well as affect other organisms (Dorgham 2014; Glibert 2017). Conversely, a greater variety of nonHAB phytoplankton indicates a thriving phytoplankton community that can support the life of other organisms.

The results indicate that changes in water quality may occur at the study sites, but these changes can still be tolerated by non-HAB phytoplankton. In addition to the taxonomic composition, the abundance of each taxon also plays a role in determining the quality of the microalgal community present. Good quality means, inter alia, that non-HAB phytoplankton abundance substantially exceeds that of HAB phytoplankton (Glibert 2017). As this was the case at all study sites and observation periods, there is a reasonable likelihood that the waters are still in good condition and have not significantly changed, as shown by the relative abundance of HAB phytoplankton and nonHAB phytoplankton (Figure 5). The types of phytoplankton present can mostly be considered of good quality for supporting the life of other organisms, including fish and shellfish. Their presence also indicates that fisheries produced from the study sites should be fit and safe for consumption, as contamination from $\mathrm{HAB}$ taxa is very unlikely at the low levels detected. This information is certainly encouraging for coastal communities, as their seafood is still suitable for consumption concerning HABs.

In conclusion, the observed composition of the marine microalgal communities present in the coastal waters along the west coast of South Sulawesi indicates that the phytoplankton quality can be considered reasonable. This evaluation is based on the taxonomic composition and abundance of non-harmful (non-HAB) phytoplankton, which was far more abundant than the taxa, which can cause HABs. This shows that seafood is still suitable for consumption because HAB taxa can be considered not yet present at contaminating levels. Even though the proportions of $\mathrm{HAB}$ forming taxa present were very low, their presence is an early warning that vigilance is needed. These results highlight the importance of maintaining water quality and the necessity of regular water quality monitoring, as suggested by Anderson et al. (2015), to ensure that HABs do not develop undetected.

\section{ACKNOWLEDGEMENTS}

The authors wish to thank the Rector of Universitas Hasanuddin for a research grant provided through the Universitas Hasanuddin Research and Community Service Institute (LP2M) under the 2020 Basic Research scheme.

\section{REFERENCES}

Aditya V, Koswara A, Fitriya N, Rachman A, Sidabutar T, Thoha H. 2015. Public awareness on harmful algal bloom (HAB) in Lampung Bay. Mar Res Indones 38 (2): 71-75. DOI: 10.14203/mri.v38i2.58.

Adnan Q. 1984. Distribution of dinoflagellates at Jakarta Bay, Taman Jaya, Banten and Benoa Bay, Bali: A report of an incident of fish poisoning at eastern Nusa Tenggara. In: Toxic Red Tides and Shellfish Toxicity in Southeast Asia, Changi Point, Singapore, Southeast Asia Fisheries Development Center and International Development Research Center (SEAFDEC).

Adnan Q. 1989. Red tides due to Noctiluca scintillans (MacCartney) Ehrenb, and mass mortality of fish in Jakarta Bay. In: Okaichi TD, Anderson DM, Nemoto T (eds). Red Tides, Biology, Environmental Science and Toxicology. Elsevier, New York.

Anderson CR, Moore SK, Tomlinson MC, Silke J, Cusack CK. 2015. Living with Harmful Algal Blooms in a Changing World. In: Shroder JF, Ellis JT, Sherman DJ (eds). Coastal and Marine Hazards, Risks, and Disasters. Elsevier, New York.

Angara, EV, Rillon GS, Carmona ML, Ferreras JEM, Vallejo MI, Amper AC, Lacuna ML. 2013. Diversity and abundance of phytoplankton in Casiguran waters, Aurora Province, Central Luzon, northern Philippines. AACL Bioflux 6 (4): 358-377.

Baek SH, Lee M, Park BS, Lim YK. 2020. Variation in phytoplankton community due to an autumn typhoon and winter water turbulence in southern Korean coastal waters. Sustainability 12 (7): 2781. DOI: $10.3390 / \mathrm{su} 12072781$

Berdalet E, Fleming LE, Gowen R, Davidson K, Hess P, Backer LC, Moore SK, Hoagland P, Enevoldsen H. 2016. Marine harmful algal blooms, human health and wellbeing: Challenges and opportunities in the 21st century. J Mar Biol Assoc 96: 61-91. DOI: 10.1017/S0025315415001733.

Berdalet E, Kudela RM, Banas NS, Bresnan E, Burford MA, Davidson K, Gobler CJ, Karlson B, Lim PT, Mackenzie L. 2018. GlobalHAB: Fostering international coordination on harmful algal bloom research in aquatic systems. In: Glibert PM, Berdalet E, Burford MA, Pitcher GC, Zhou M (eds). Global Ecology and Oceanography of Harmful Algal Blooms. Springer, Germany.

Brahem M, Eder S, Renard CMGC, Loonis M, Le Bourvellec C. 2017. Effect of maturity on the phenolic compositions of pear juice and cell wall effects on procyanidins transfer. LWT 85: 380-384. DOI: 10.1016/j.lwt.2016.09.009.

Brett MT, Kainz MJ, Taipale SJ, Seshan H. 2009. Phytoplankton, not allochthonous carbon, sustains herbivorous zooplankton production. Proc Natl Acad Sci 106: 21197-21201. DOI: 10.1073/pnas.090412910.

Brown AR, Lilley M, Shutler J, Lowe C, Artioli Y, Torres R, Berdalet E, Tyler CR. 2019. Assessing risks and mitigating impacts of harmful algal blooms on mariculture and marine fisheries. Rev Aquac 12: 12403. DOI: 10.1111/raq.12403.

Castellani C, Edwards M. 2017. Marine Plankton: A Practical Guide to Ecology, Methodology, and Taxonomy. Oxford University Press, United Kingdom.

Cavicchioli R, Ripple WJ, Timmis KN, Azam F, Bakken LR, Baylis M, Behrenfeld MJ, Boetius A, Boyd PW, Classen AT, Crowther TW, Danovaro R, Foreman CM, Huisman J, Hutchins DA, Jansson JK, Karl DM, Koskella B, Mark WDB, Martiny JBH, Moran MA, Orphan VJ, Reay DS, Remais JV, Rich VI, Singh BK, Stein LY, Stewart FJ, Sullivan MB, van Oppen MJH, Weaver SC, Webb EA, Webster NS. 
2019. Scientists' warning to humanity: microorganisms and climate change. Nat Rev Microbiol 17: 569-586. DOI: 10.1038/s41579-0190222-5.

Cui L, Lu X, Dong Y, Cen J, Cao R, Pan L, Lu S, Ou L. 2018. Relationship between phytoplankton community succession and environmental parameters in Qinhuangdao coastal areas, China: A region with recurrent brown tide outbreaks. Ecotoxicol Environ Saf 159: 85-93. DOI: 10.1016/j.ecoenv.2018.04.043.

D'Costa PM, D'Silva MS, Naik RK. 2017. Impact of pollution on phytoplankton and implications for marine Econiches. In: Naik MM, Dubey SK (eds). Marine Pollution and Microbial Remediation. Springer, Singapore.

Desrosiers C, Leflaive J, Eulin A, Ten-Hage L. 2013. Bioindicators in marine waters: Benthic diatoms as a tool to assess water quality from eutrophic to oligotrophic coastal ecosystems. Ecol Indic 32: 25-34. DOI: 10.1016/j.ecolind.2013.02.021.

Dietrich J, Sommersdorf C, Gohlke S, Poetz O, Traenkle B, Rothbauer U, Hessel-Pras S, Lampen A, Braeuning A. 2019. Okadaic acid activates Wnt/ $\beta$-catenin-signaling in human HepaRG cells. Arch Toxicol 93 (7): 1927-1939. DOI: 10.1007/s00204-019-02489-4

Dorgham MM. 2014. Effects of eutrophication. In: Ansari AA, Gill SS (eds). Eutrophication: Causes, Consequences and Control. Springer, Dordrecht, Netherlands.

Dzhembekova N, Moncheva S, Ivanova P, Slabakova N, Nagai S. 2018 Biodiversity of phytoplankton cyst assemblages in surface sediments of the Black Sea based on metabarcoding. Biotechnol Biotechnol Equip 32 (6): 1507-1513. DOI: 10.1080/13102818.2018.1532816.

Farabegoli F, Blanco L, Rodríguez LP, Vieites JM, Cabado AG. 2018. Phycotoxins in marine shellfish: Origin, occurrence and effects on humans. Mar Drugs 16 (6): 188. DOI: 10.3390/md16060188.

Ferreira A, Sá C, Silva N, Beltrán C, Dias AM, Brito AC. 2020 Phytoplankton response to nutrient pulses in an upwelling system assessed through a microcosm experiment (Algarrobo Bay, Chile). Ocean Coast Manag 190: 105167. DOI 10.1016/j.ocecoaman.2020.105167

Fu F, Tatters A, Hutchins D. 2012. Global change and the future of harmful algal blooms in the ocean. Mar Ecol Prog Ser 470: 207-233. DOI: $10.3354 / \mathrm{meps} 10047$.

Fujiwara A, Nishino S, Matsuno K, Onodera J, Kawaguchi Y, Hirawake T, Suzuki K, Inoue J, Kikuchi T. 2018. Changes in phytoplankton community structure during wind-induced fall bloom on the central Chukchi shelf. Polar Biol 41: 1279-1295. DOI: 10.1007/s00300-0182284-7.

Fukuyo Y, Kodama M, Omura T, Furuya K, Furio EF, Cayme M, Teen LP, Ha DV, Kotaki Y, Matsuoka K, Iwataki M, Sriwoon R, Lirdwitayaprasit T. 2011. Ecology and oceanography of harmful marine microalgae (Project-2). In: Nishida, Fortes MD, Miyazaki N (eds). Coastal Marine Science in Southeast Asia-Synthesis Report of the Core University Program of the Japan Society for the Promotion of Science: Coastal Marine Science (2001-2010). TERRAPUB, Japan.

Gao P, Wang P, Chen S, Bi W, Lu S, He J, Wang X, Li K. 2020. Effect of ambient nitrogen on the growth of phytoplankton in the Bohai Sea: Kinetics and parameters. J Geophys Res Biogeosci 125 (12) e2020JG005643. DOI: 10.1029/2020JG005643.

George B, Kumar JIN, Kumar RN. 2012. Study on the influence of hydrochemical parameters on phytoplankton distribution along Tap estuarine area of Gulf of Khambhat, India. Egypt J Aquat Res 38 (3): 157-170. DOI: 10.1016/j.ejar.2012.12.010.

Glibert PM. 2017. Eutrophication, harmful algae and biodiversitychallenging paradigms in a world of complex nutrient changes. Mar Pollut Bull 124: 591-606. DOI: 10.1016/j.marpolbul.2017.04.027.

Glibert PM. 2020. Harmful algae at the complex nexus of eutrophication and climate change. Harmful Algae 91: 101583. DOI 10.1016/j.hal.2019.03.001.

Hasani Q, Adiwilaga EM, Pratiwi NTM. 2013. The relationship between the harmful algal blooms (HABs) phenomenon with nutrients at shrimp farms and fish cage culture sites in Pesawaran District Lampung Bay. Makara J Sci 16 (3): 183-191. DOI 10.7454/mss.v16i3.1480.

Hughes BB, Haskins JC, Wasson K, Watson E. 2011. Identifying factors that influence expression of eutrophication in a central California estuary. Mar Ecol Prog Ser 439: 31-43. DOI: 10.3354/meps09295.

Krock B, Ferrario ME, Akselman R, Nora G. 2018. Occurrence of marine biotoxins and shellfish poisoning events and their causative organisms in Argentine marine waters. Oceanogr 31 (4): 132-144. DOI: 10.5670/oceanog.2018.403

Kudela RM, Raine R, Pitcher GC, Gentien P, Berdalet E, Enevoldsen H, Urban E. 2018. Establishment, Goals, and Legacy of the Global Ecology and Oceanography of Harmful Algal Blooms (GEOHAB) programme. In: Glibert P, Berdalet E, Burford M, Pitcher G, Zhou M (eds). Global Ecology and Oceanography of Harmful Algal Blooms. Ecological Studies (Analysis and Synthesis). Springer, Germany.

Lassus P, Chomérat N, Hess P, Nézan E. 2016. Toxic and Harmful Microalgae of the World Ocean. IOC Manuals and Guides No. 68. Intergovernmental Oceanographic Commission of UNESCO, Copenhagen.

Lestari HA, Samawi MF, Faizal A, Moore AM, Jompa J. 2021. Diversity and abundance of phytoplankton in the Coastal Waters of South Sulawesi. HAYATI J Biosci 28: 199-211. DOI: 10.4308/hjb.28.3.199.

Loureiro S, Reñé A, Garcés E, Camp J, Vaqué D. 2011. Harmful algal blooms (HABs), dissolved organic matter (DOM), and planktonic microbial community dynamics at a near-shore and a harbour station influenced by upwelling (SW Iberian Peninsula). J Sea Res 65 (4): 401-413. DOI: 10.1016/j.seares.2011.03.004.

Lu Y, Yuan J, Lu X, Su C, Zhang Y, Wang C, Cao X, Li Q, Su J, Ittekkot V, Garbutt RA, Bush S, Fletcher S, Wagey T, Kachur A, Sweijd N. 2018. Major threats of pollution and climate change to global coastal ecosystems and enhanced management for sustainability. Environ Pollut 239: 670-680. DOI: 10.1016/j.envpol.2018.04.016.

Mahmudi M, Serihollo LG, Herawati EY, Lusiana ED, Buwono RE. 2020. A count model approach on the occurrences of harmful algal blooms (HABs) in Ambon Bay. Egypt J Aquat Res 46 (4): 347-353. DOI: 10.1016/j.ejar.2020.08.002.

Marinov I, Doney SC, Lima ID. 2010. Response of ocean phytoplankton community structure to climate change over the 21 st century: Partitioning the effects of nutrients, temperature and light. Biogeosciences 7 (12): 3941-3959. DOI: 10.5194/bg-7-3941-2010.

Meesters E, Tapilatu RF. 2020. First dive Raja Ampat, Sorido. https://weblog.wur.eu/coastsea/first-dive-raja-ampat-sorido/.

Mujib AS, Damar A, Wardiatno Y. 2015. Spatial distribution of planktonic dinoflagellate in Makassar waters, South Sulawesi. J Mar Sci Technol 7: 479-492. DOI: 10.29244/jitkt.v7i2.11033.

Narale DD, Anil AC. 2017. Spatial distribution of dinoflagellates from the tropical coastal waters of the South Andaman, India: Implications for coastal pollution monitoring. Mar Pollut Bull 115: 498-506. DOI: 10.1016/j.marpolbul.2016.11.035

Paerl HW, Otten TG, Kudela R. 2018. Mitigating the expansion of harmful algal blooms across the freshwater-to-marine continuum. Environ Sci Technol 52: 5519-5529. DOI: 10.1021/acs.est.7b05950.

Pettersson LH, Pozdnyakov D. 2013. Qualification, species variety, and consequences of harmful algal blooms (HABs). Monitoring of Harmful Algal Blooms. Springer, Berlin, Heidelberg.

Pitcher GC, Probyn TA. 2016. Suffocating phytoplankton, suffocating waters-red tides and anoxia. Front Mar Sci 3: 186. DOI: 10.3389/fmars.2016.00186.

Praseno DP, Sugestiningsih. 2000. Retaid in Indonesian Waters. Center for Research and Development of Oceanology. Indonesian Institute of Sciences, Jakarta. [Indonesian]

Rastina, Nurjaya IW, Prartono T, Sanusi H. 2020. Monsoonal distribution of phosphate within Tallo Estuary, South of Sulawesi. IOP Conf Ser Earth Environ Sci 429: 012023. DOI: 10.1088/17551315/429/1/012023.

Rocha FC, Andrade EM, Lopes FB. 2015. Water quality index calculated from biological, physical and chemical attributes. Environ Monit Assess 187 (4163): 1-15. DOI: 10.1007/s10661-014-4163-1.

Rodrigues SM, de Carvalho M, Mestre T, Ferreira JJ, Coelho M, Peralta R, Vale P. 2012. Paralytic shellfish poisoning due to ingestion of Gymnodinium catenatum contaminated cockles-application of the AOAC HPLC official method. Toxicon 59 (5): 558-566. DOI: 10.1016/j.toxicon.2012.01.004.

Rukminasari N, Tahir A. 2020. Species assemblages and distribution of Dinoflagellate cysts from three estuaries sediment's of Makassar Strait, Eastern Indonesia. Online J Biol Sci 21 (2): 232-244. DOI: 10.3844/ojbsci.2021.232.244

Samawi MF, Tahir A, Tambaru R, Amri K, Lanuru M, Armi NK. 2020. Phytoplankton and physics chemical parameters in estuary waters, West Coast of South Sulawesi, Indonesia. Torani J Fish Mar Sci 3: 61-70. DOI: 10.35911/torani.v3i2.11370.

Sha J, Xiong H, Li C, Lu Z, Zhang J, Zhong H, Zhang W, Yan B. 2021. Harmful algal blooms and their eco-environmental indication. 
Chemosphere 274: $129912 . \quad$ DOI 10.1016/j.chemosphere.2021.129912.

Shadrin NV, Anufriieva EV, Belyakov VP, Bazhora AI. 2017. Chironomidae larvae in hypersaline waters of the Crimea: Diversity, distribution, abundance and production. Eur Zool J 84 (1): 61-72. DOI: $10.1080 / 11250003.2016 .1273974$

Skinner MP, Lewis RJ, Morton S. 2011. The abundance of potentially toxic epiphytic dinoflagellates and nutrients from Bali and Gili Trawangan, Indonesia. Mar Res Indones 36 (2): 11-23. DOI: 10.14203/mri.v36i2.38

Sunda WG. 2012. Feedback interactions between trace metal nutrients and phytoplankton in the ocean: A Review. Front Microbiol 3: 204. DOI: 10.3389/fmicb.2012.00204

Sunesen I, Hernández BDU, Sar EA. 2008. Marine diatoms from Buenos Aires coastal waters (Argentina). V. Species of the genus Chaetoceros. Rev Biol Mar Oceanogr 43 (2): 303-326. DOI: 10.4067/S0718-19572008000200009.

Takarina ND, Nurliansyah W, Wardhana W. 2019. Relationship between environmental parameters and the plankton community of the Batuhideung Fishing Grounds. Biodiversitas 20 (1): 171-180. DOI 10.13057/biodiv/d200120.

Taylor M, McIntyre L, Ritson M, Stone J, Bronson R, Bitzikos O, Rourke W, Galanis E, Team OI. 2013. Outbreak of diarrhetic shellfish poisoning associated with mussels, British Columbia, Canada. Mar Drugs 11 (5): 1669-1676. DOI: 10.3390/md11051669.

Tester PA, Litaker RW, Berdalet E. 2020. Climate change and harmful benthic microalgae. Harmful Algae 91: 101655. DOI 10.1016/j.hal.2019.101655.

Thoha H, Rachman A. 2012. Temporal variation in Ceratium spp abundance recorded in Jakarta Bay. Mar Res Indones 37 (1): 35-45. DOI: $10.14203 / \mathrm{mri} . v 37 \mathrm{i1} .35$.

Thovyan AI, Tapilatu RF, Sabariah V, Venables SK. 2020. Plankton abundance and community structure in reef manta ray (Mobula alfredi) feeding habitat in the Dampier Strait, Raja Ampat, West Papua, Indonesia. AACL Bioflux 13 (5): 2956-2969.

Tian R, Chen J, Sun X, Li D, Liu C, Weng H. 2018. Algae explosive growth mechanism enabling weather-like forecast of harmful algal blooms. Sci Rep 8 (1): 1-7. DOI: 10.1038/s41598-018-28104-7.

Tillmann U, Elbrächter M, John U, Krock B, Cembella A. 2010. Azadinium obesum (Dinophyceae), a new nontoxic species in the genus that can produce azaspiracid toxins. Phycologia 49 (2): 169182. DOI: $10.2216 /$ PH09-35.1.

Todd PA, Heery EC, Loke LH, Thurstan RH, Kotze DJ, Swan C. 2019 Towards an urban marine ecology: Characterizing the drivers, patterns and processes of marine ecosystems in coastal cities. Oikos 128 (9): 1215-1242. DOI: 10.1111/oik.05946.

Tomas. 1997. Identifying Marine Phytoplankton. Academic Press, Cambridge

Trainer VL, Moore L, Bill BD, Adams NG, Harrington N, Borchert J, Da Silva DAM, Eberhart B-TL. 2013. Diarrhetic shellfish toxins and other lipophilic toxins of human health concern in Washington State. Mar Drugs 11 (6): 1815-1835. DOI: 10.3390/md11061815.

Trainer VL, Moore SK, Hallegraeff G, Kudela RM, Clement A, Mardones JI, Cochlan WP. 2020. Pelagic harmful algal blooms and climate change: Lessons from nature's experiments with extremes. Harmful Algae 91: 101591. DOI: 10.1016/j.hal.2019.03.009.

Vadrucci MR, Roselli L, Castelluccia D, di Festa T, Donadei D, Florio M, Longo E, D'Arpa S, Maci F, Ranieri S, Spinelli M, Pastorelli A, Ungaro N 2018. PhytoNumb3rs: An easy-to-use computer toolkit for counting microalgae by the Utermöhl method. Ecol Inform 46: 147155. DOI: 10.1016/j.ecoinf.2018.06.007.

Vajravelu M, Martin Y, Ayyappan S, Mayakrishnan M. 2018. Seasonal influence of physico-chemical parameters on phytoplankton diversity, community structure and abundance at Parangipettai coastal waters, Bay of Bengal, South East Coast of India. Oceanologia 60: 114-127. DOI: 10.1016/j.oceano.2017.08.003.

Visciano P, Schirone M, Berti M, Milandri A, Tofalo R, Suzzi G. 2016. Marine biotoxins: occurrence, toxicity, regulatory limits and reference methods. Front Microbiol 7: 1051. DOI: 10.3389/fmicb.2016.01051.

Wells ML, Trainer VL, Smayda TJ, Karlson BSO, Trick CG, Kudela RM, Ishikawa A, Bernard S, Wulff A, Anderson DM, Cochlan WP. 2015. Harmful algal blooms and climate change: Learning from the past and present to forecast the future. Harmful Algae 49: 68-93. DOI: 10.1016/j.hal.2015.07.009.

Work TM, Moeller PDR, Beauchesne KR, Dagenais J, Breeden R, Rameyer R, Walsh WJ, Abecassis M, Kobayashi DR, Conway C, Winton J. 2017. Pufferfish mortality associated with novel polar marine toxins in Hawaii. Dis Aquat Organ 123 (2): 87-99. DOI: 10.3354/dao03096.

Xiao X, Agustí S, Pan Y, Yu Y, Li K, Wu J, Duarte CM. 2019. Warming amplifies the frequency of harmful algal blooms with eutrophication in Chinese coastal waters. Environ Sci Technol 53 (22): 1303113041. DOI: 10.1021/acs.est.9b03726.

Zohdi E, Abbaspour M. 2019. Harmful algal blooms (red tide): A review of causes, impacts and approaches to monitoring and prediction. Intl $\mathrm{J}$ Environ Sci Technol 16 (3): 1789-1806. DOI: 10.1007/s13762-0182108-x 